\title{
Poorly Marginated Nodule
}

National Cancer Institute

\section{Source}

National Cancer Institute. Poorly Marginated Nodule. NCI Thesaurus. Code C157664.

The nodule margin blends into adjacent lung without clear demarcation between nodule edge and normal lung (i.e., the entire circumference of the nodule can't be drawn with confidence). This is to be distinguished from faint (but definable) margination, as with subsolid nodules. 